\title{
Contents of $\mathrm{Zn}, \mathrm{Cu}, \mathrm{Mn}$ and Se in Milk in Relation to their Concentrations in Blood, Milk Yield and Stage of Lactation in Dairy Cattle
}

\author{
A. PECHOVÁ, L. PAVLATA, R. DVOŘÁK, E. LOKAJOVÁ \\ Clinic of Ruminants Diseases, Faculty of Veterinary Medicine, \\ University of Veterinary and Pharmaceutical Sciences Brno, \\ Czech Republic
}

Received September 21, 2007

Accepted June 11, 2008

\begin{abstract}
Pechová A., L. Pavlata, R. Dvořák, E. Lokajová: Contents of Zn, Cu, Mn and Se in Milk in Relation to their Concentrations in Blood, Milk Yield and Stage of Lactation in Dairy Cattle. Acta Vet. Brno 2008, 77: 523-531.

The objective of the study was to assess the effect of actual daily milk production and lactation stage on concentrations of $\mathrm{Zn}, \mathrm{Mn}, \mathrm{Cu}$ and $\mathrm{Se}$ in milk, and monitor correlations between milk and blood concentrations of these microelements.

The study was performed in a herd of Holstein cattle with the average milk yield of $8,562 \mathrm{~kg}$. Thirty-five dairy cows housed in one group were included in the study. Blood and milk samples were taken during two separate milk yield checks done 4 weeks apart. Actual milk production of monitored cows ranged from 19.6 to 62.61 daily. For lactation stages we evaluated results of examinations performed from 7 to 188 days of lactation.

Blood examinations showed that the cows included in our study had good supplementation with the microelements in question. Milk concentrations of individual microelements were as follows: $3855.2 \pm 814.7 \mu \mathrm{g} / \mathrm{l}$ of $\mathrm{Zn} ; 36.3 \pm 14.4 \mu \mathrm{g} / \mathrm{l}$ of $\mathrm{Cu} ; 20.1 \pm 8.3 \mu \mathrm{g} / \mathrm{l}$ of $\mathrm{Mn}$, and $28.6 \pm 7.1$ $\mu \mathrm{g} / \mathrm{l}$ of Se. The effect of daily milk production on milk concentrations of the microelements was identified only for copper $(\mathrm{r}=-0.302, p \leq 0.05)$. The variable of days of lactation (not considering days of the colostrum period) showed a positive correlation in manganese $(\mathrm{r}=0.419, p \leq 0.01)$; copper and selenium showed negative correlations $(\mathrm{Cu}: \mathrm{r}=-0.258, p \leq 0.05$; Se: $\mathrm{r}=-0.277$, $p \leq 0.05$ ). The daily milk production influenced negatively only $\mathrm{Cu}$ concentration in milk, but $\mathrm{Se}$, $\mathrm{Zn}$ and $\mathrm{Mn}$ was not influenced. With advancing lactation after colostrum period the concentration of $\mathrm{Mn}$ in milk raised, the concentration of $\mathrm{Cu}$ and Se declined and the concentration of $\mathrm{Zn}$ was unchanged.
\end{abstract}

Cows, microelements, blood plasma

Today, selenium, copper, zinc, manganese and iodine are the most often analyzed microelements. Although veterinary studies focus mainly on their effect on the health of farm animals, increasing emphasis has been lately put also on their impact on the quality of food. Moreover, dietary supplementation with microelements enhances the nutritive value of food. Cows' milk concentration of zinc ranges from $2-6 \mathrm{mg} / \mathrm{l}$, copper $0.1-0.6$ $\mathrm{mg} / \mathrm{l}$, manganese 20-50 $\mu \mathrm{g} / \mathrm{l}$ and selenium 2-60 $\mu \mathrm{g} / \mathrm{l}$ (Knowles et al. 2006). Comparison of these values with the daily requirements of 4- to 6-month-old children (i.e., $5 \mathrm{mg}$ of $\mathrm{Zn}$; $0.4-0.6 \mathrm{mg}$ of $\mathrm{Cu} ; 0.01 \mathrm{mg}$ of Se and $0.3-0.6 \mathrm{mg}$ of $\mathrm{Mn}$ [Milner 1990]) shows that milk might be an important source of these micronutrients. The scope for increasing concentration of micronutrients in milk is limited by the complex and co-coordinated biochemical mechanisms of animal homeostasis. The transition element cations $(\mathrm{Cu}, \mathrm{Mn}$, $\mathrm{Zn}$ ) have concentrations in blood, tissues and milk that are largely independent of the intake, as they relate to regulation of gut absorption and changing metabolic demands (Windisch 2002). In contrast, small anion such as Se is readily transported across membranes of the digestive tract. For this reason, selenium concentration in milk is greatly influenced by its dietary intake. Knowles et al. (2006) summarize the results of some reports of research in

Address for correspondence:

Doc. MVDr. Alena Pechová, CSc.

Clinic of Ruminant Diseases

Faculty of Veterinary Medicine

University of Veterinary and Pharmaceutical Sciences Brno

Palackého 1-3, 61242 Brno, Czech Republic

Phone: + 420541562408

Fax.: + $420541562413+$

E-mail: pechovaa@vfu.cz

http://www.vfu.cz/acta-vet/actavet.htm 
dairy cows concerning the responsiveness of milk to dietary supplementation as follows: $\mathrm{Se} \approx \mathrm{I}>>\mathrm{Zn} \approx \mathrm{Cu}>\mathrm{Ca} \approx \mathrm{Fe} \approx \mathrm{Mn}$.

The issue of micronutrients contained in milk is generally neglected and the factors affecting their concentrations are not known. Although many authors confirmed the variability of milk concentration of individual microelements, specific factors have not been satisfactorily identified. The majority of experiments have focused on selenium; less attention has been paid to zinc and copper. Milk concentration of manganese has been studied rarely.

The aim of our study was therefore to assess the effect of actual daily milk production and lactation stage on concentrations of $\mathrm{Zn}, \mathrm{Mn}, \mathrm{Cu}$ and $\mathrm{Se}$ in milk, and monitor the correlations between milk and blood concentrations of these microelements.

\section{Materials and Methods}

The study was performed at a farm with 161 Holstein cows located in Northern Bohemia. The average milk production of this herd was $8,562 \mathrm{~kg}$ of milk per lactation, with $3.61 \%$ of fat ( $310 \mathrm{~kg}$ of fat per lactation) and $3.17 \%$ of protein ( $272 \mathrm{~kg}$ of protein per lactation) on average. Dairy cows were divided into groups and kept in loose housing. Thirty-five dairy cows housed in one group were included in our study. Blood and milk samples were taken during two separate milk production checks. During the study, the animals were fed the same total mixed ration. The content of individual microelements per $1 \mathrm{~kg}$ of dry matter was as follows: $105 \mathrm{mg} / \mathrm{kg}$ of Zn, 17 $\mathrm{mg} / \mathrm{kg}$ of Cu, $66 \mathrm{mg} / \mathrm{kg}$ of $\mathrm{Mn}$ and $0.4 \mathrm{mg} / \mathrm{kg}$ of Se. Nutrient composition of this feed ration is specified in Table 1 . Average consumption of dry matter (DM) was $20.5 \mathrm{~kg}$. The cows included in the study were in the first half of their

Table 1 . The composition of daily feed ration $(650 \mathrm{~kg}$, milk yield $35 \mathrm{l})$

\begin{tabular}{|l|r|c|}
\hline Dry matter & $\mathrm{g}$ & 23190 \\
\hline Metabolisable energy & Mcal & 39.32 \\
\hline Crude protein & $\mathrm{g}$ & 4300 \\
\hline Acid detergent fibre & $\mathrm{g}$ & 4500 \\
\hline Neutral detergent fibre & $\mathrm{g}$ & 7600 \\
\hline Starch & $\mathrm{g}$ & 4300 \\
\hline Fat & $\mathrm{g}$ & 1300 \\
\hline Ash & $\mathrm{g}$ & 1420 \\
\hline Copper & $\mathrm{mg}$ & 394 \\
\hline Manganese & $\mathrm{mg}$ & 1530 \\
\hline Zinc & $\mathrm{mg}$ & 2435 \\
\hline Selenium & $\mathrm{mg}$ & 9.28 \\
\hline
\end{tabular}

M6 appliance (Unicam, Great Britain). Before measuring, serum samples were deproteinized by supplementing trichloroacetic acid at a $1: 1$ ratio. After centrifugation, we measured the content of $\mathrm{Zn}$ and $\mathrm{Cu}$ in the supernatant.

In order to measure the concentration of $\mathrm{Mn}$ in whole blood and $\mathrm{Zn}, \mathrm{Cu}$ and $\mathrm{Mn}$ in milk, we had to mineralize the samples via wet-processing treatment with the supplement of hydrogen peroxide and nitric acid ( $2 \mathrm{ml}$ of milk [blood] $+1 \mathrm{ml} \mathrm{H}_{2} \mathrm{O}_{2}+2 \mathrm{ml} \mathrm{HNO}_{3}$ ). We applied the microwave digestion technique using microwave ashing system MLS-1200 (Milestone, Italy). Zn was identified in the mineralisate by flame atomic absorption spectrophotometry using Solaar M6 (Unicam, Great Britain). Cu and Mn contents were measured via electrothermic atomic absorption spectrophotometry using Solaar 939 (Unicam, Great Britain).

Milk and whole blood concentration of Se was determined after mineralization of samples by hydride technique using Solaar M6 (Unicam, Great Britain) with electrothermically heated cuvette as per methodology designed by Pechová et al. (2005). All analyses were performed by the laboratory of the Clinic of Ruminant Diseases of the University of Veterinary and Pharmaceutical Sciences Brno.

Each set of samples was subjected to basic statistical evaluations (mean, standard deviation, median, quartiles, maximum, and minimum). Correlations between milk production, lactation stage, and concentration of individual microelements in blood and milk were identified by correlation analysis. The assessment was carried out using Microsoft Windows ${ }^{X P}$ Excel software.

\section{Results and Discussion}

The effect of actual daily milk production and lactation stage (days of lactation) on the concentration of microelements in milk was evaluated (a total of 70 data for each 
element). The actual daily milk production of monitored cows ranged from 19.6 to 62.61 . The average daily milk production was 36.61 . For lactation stages we evaluated the results of examinations performed from 7 to 188 days after parturition (105.4 days at the average). A rather wide dispersion of milk production and lactation stage indicators was chosen intentionally in order to acquire the broadest possible spectrum at the same feed ration.

Results of blood examinations showed a good supplementation with microelements in the cows under study. The concentration of $\mathrm{Cu}$ in blood serum of animals was $826.75 \pm$ $138.08 \mu \mathrm{g} / \mathrm{l}(13.0 \pm 2.17 \mu \mathrm{mol} / \mathrm{l})$, and no dairy cow showed values lower than $572 \mu \mathrm{g} / \mathrm{l}$ (Underwood and Suttle 1999), which is the threshold indicating satisfactory copper supplementation. Selenium contents were very good too, as no cow showed values lower than $100 \mu \mathrm{g} / \mathrm{l}$ (Pavlata et al. 2000). Blood concentration of Se was $183.75 \pm 29.63$ $\mu \mathrm{g} / \mathrm{l}(2.33 \pm 0.38 \mu \mathrm{mol} / \mathrm{l})$. Blood serum concentration of $\mathrm{Zn}$ was $1063.92 \pm 181.13 \mu \mathrm{g} / \mathrm{l}$ $(16.27 \pm 2.77 \mu \mathrm{mol} / \mathrm{l})$. Only two samples showed slightly decreased $\mathrm{Zn}$ concentrations that dropped below $600 \mu \mathrm{g} / \mathrm{l}$ (Underwood and Suttle 1999). This was probably due to certain individual specifications or redistribution of $\mathrm{Zn}$ in the organism. Blood concentration of $\mathrm{Zn}$ can drop by up to $50 \%$ due to high stress, trauma or inflammatory processes (Zadák 2002).

The average concentration of $\mathrm{Mn}$ in blood was $14.03 \pm 3.24 \mu \mathrm{g} / \mathrm{l}(0.26 \pm 0.06 \mu \mathrm{mol} / \mathrm{l})$, which is lower than the reference range for cattle $(20-70 \mu \mathrm{g} / \mathrm{l})$ reported by Underwood and Suttle (1999). However, Underwood's concentrations are relatively high and we noted lower values. For example, Gehrke and Lachowski (1997) found that the concentration of $\mathrm{Mn}$ in lactating cows ranged from 1.55 to $4.85 \mu \mathrm{gl} / \mathrm{l}$ in blood serum and from 5.10 to $12.35 \mu \mathrm{gl} / \mathrm{l}$ in blood. These values are comparable with our findings. According to Gelfert and Staufenbiel (2000), the values for diagnosing the deficiency disease reported in various studies $(6 \mu \mathrm{gl} / \mathrm{l}$ in blood serum) are too high, as the screening carried out at 70 farms in Germany showed lower values, which would, in fact, point to Mn deficiency disease. Considering the rather high content of $\mathrm{Mn}$ in the feed ration of cows included in our study, we do not believe they suffered from the Mn deficiency disease. Hansen et al. (2006) reported that $15.8 \mathrm{mg}$ of $\mathrm{Mn}$ per $1 \mathrm{~kg}$ of dry matter (DM) is sufficient. In fact, this value is several-fold lower than the concentrations in our study. Results of various studies indicate that their authors have different views on the role of blood concentration of $\mathrm{Mn}$ as indicator of overall Mn supplementation. Legleiter et al. (2005) suggest that serum concentration of Mn does not reflect the level of $\mathrm{Mn}$ supplementation. The distribution of the concentrations of monitored microelements in blood and blood serum are specified in Fig. 1, in milk in Fig. 2 and Fig. 3.
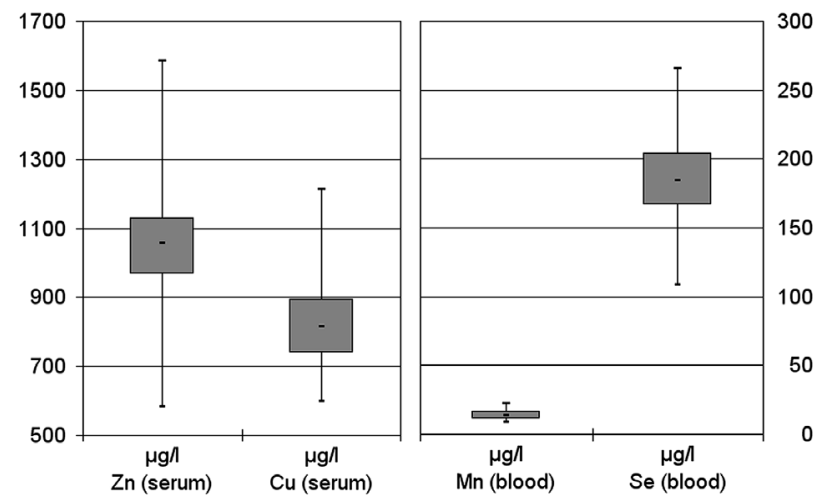

Fig. 1. Distribution (maximum, quartile $75 \%$, median, quartile $25 \%$, minimum) of the concentration of microlements in serum/blood of dairy cows $(n=70)$ 

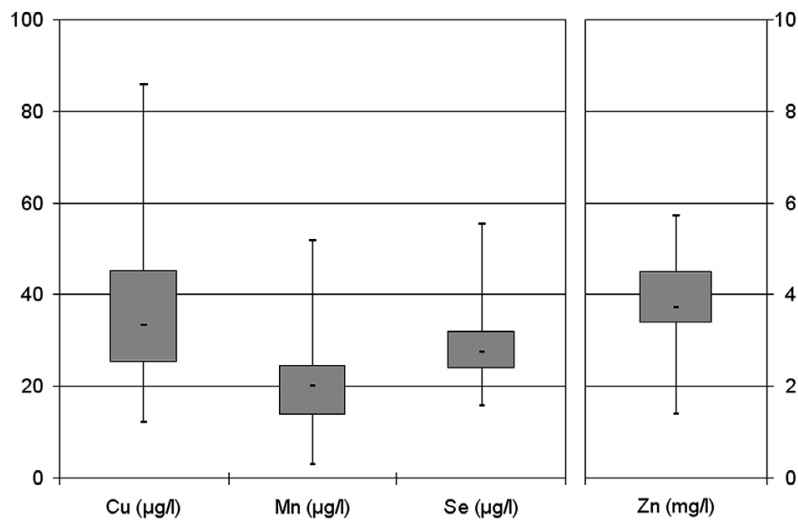

Fig. 2. Distribution (maximum, quartile $75 \%$, median, quartile $25 \%$, minimum) of the concentration of microlements in milk of dairy cows $(n=70)$
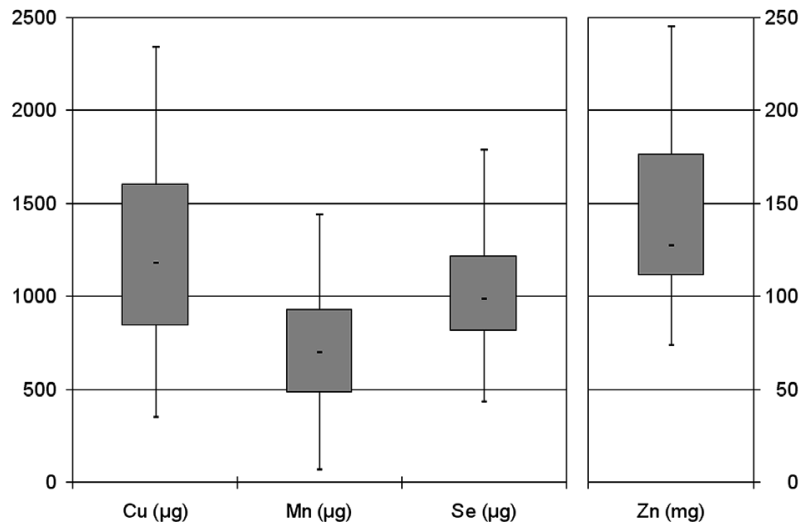

Fig. 3. Distribution (maximum, quartile $75 \%$, median, quartile $25 \%$, minimum) of the total amounts of individual microelements excreted in milk in 1 day $(n=70)$

Table 2. Comparison of the concentration of microelements in raw cow milk based on literature

\begin{tabular}{|c|c|c|c|c|}
\hline $\begin{array}{c}\text { Zn in milk } \\
(\mu \mathrm{g} / \mathrm{l})\end{array}$ & $\begin{array}{c}\text { Cu in milk } \\
(\mu \mathrm{g} / \mathrm{l})\end{array}$ & $\begin{array}{c}\text { Mn in milk } \\
(\mu \mathrm{g} / \mathrm{l})\end{array}$ & $\begin{array}{c}\text { Se in milk } \\
(\mu \mathrm{g} / \mathrm{l})\end{array}$ & Reference \\
\hline $3855.2 \pm 814.7$ & $36.25 \pm 14.36$ & $20.07 \pm 8.26$ & $28.59 \pm 7.12$ & This work \\
\hline $3750.8 \pm 689.21$ & & & & Pechová et al. (2006) \\
\hline $3960.0 \pm 149.1$ & $52.0 \pm 5.0$ & 21.0 & & Anderson (1992) \\
\hline $4409.2 \pm 667.0$ & $76.0 \pm 32.0$ & & $16.44 \pm 4.41$ & Rodriguez et al. (2001) \\
\hline $3419.2 \pm 18.96$ & $95.0 \pm 70.0$ & & & Martin-Hernandez et al. (1992) \\
\hline $3699.8 \pm 219.7$ & $160.0 \pm 20.0$ & & & Zurera et al. (1994) \\
\hline $4209.2 \pm 392.3$ & $155.0 \pm 35.0$ & & & Rondon et al. (1994) \\
\hline $4209.8 \pm 410.0$ & $16.0 \pm 3.0$ & & & Beneno et al. (1993) \\
\hline $4400 \pm 300$ & $100 \pm 10$ & & & Rojas et al. (1994) \\
\hline $3290 \pm 210$ & $160 \pm 30$ & $56 \pm 9$ & & Abollino et al. (1998) \\
\hline 3900 & 130 & 22 & & Licata et al. (2004) \\
\hline 2016 & 1.98 & $30 \pm 7$ & & O’Brien et al. (1999) \\
\hline $3950 \pm 380$ & $70 \pm 16$ & 30.24 & & Hermansen et al. (2005) \\
\hline $1978-10890$ & $15-178$ & $1.09-49.1$ & $0.05-223$ &
\end{tabular}


Our results are comparable with values identified by other authors. Table 2 presents a comparison of our values with concentrations established in other studies.

The zinc concentration in milk is higher than its blood serum concentration. In our study it was $3855.2 \pm 814.7 \mu \mathrm{g} / \mathrm{l}$ and the total volume of $\mathrm{Zn}$ discharged through milk was $142.87 \pm 42.42 \mathrm{mg}$. Only a few studies on the content of $\mathrm{Zn}$ in cow's milk have been published to date, and the factors affecting its concentration in milk have not been described thoroughly. In humans, $0.5-1.0 \mathrm{mg}$ of $\mathrm{Zn}$ per day is transported through the mammary gland into milk (King 2002) and Zn transportation into milk is hypothesized to be an active process (Kelleher and Lonnerdal 2003). Zinc in cow's milk primarily binds to casein and, to a small extent, citrate. Almost $90 \%$ of $\mathrm{Zn}$ binds to casein in mature milk, in contrast to just $60 \%$ in the colostrum (Kincaid and Cronrath 1992). In casein, Zn binds primarily to colloid calcium phosphate in casein micelles (Silva et al. 2001).

Copper concentration in cow's milk is rather low and, unlike zinc, its blood serum concentration is several-fold higher. In our group, it was $36.25 \pm 14.36 \mu \mathrm{g} / 1$ and a total volume of $\mathrm{Cu}$ discharged through milk was $1246.67 \pm 472.13 \mu \mathrm{g}$. Abollino et al. (1998) used speciation analysis to study distribution of $\mathrm{Cu}$ in cow's milk. Their results show that $53.7 \%$ of copper binds to casein and $40.8 \%$ of $\mathrm{Cu}$ is in cationic fraction, but no copper was identified in anionic fraction. No other fractions were specified in that study. It should be noted that $44.7 \%$ of copper in milk is in a soluble form.

Only a few data on the milk concentration of Mn have been reported. Milk Mn concentration is rather low but comparable with its concentration in blood. In our group, milk Mn concentration was $20.07 \pm 8.26 \mu \mathrm{g} / \mathrm{l}$ and a total volume of Mn discharged through milk was $716.83 \pm 316.68 \mu \mathrm{g}$. Distribution of Mn in cow's milk was studied by Abollino et al. (1998) who used speciation analysis. Their results show that only $10.4 \%$ of Mn binds to casein, $47.7 \%$ is in cationic fraction and $10.8 \%$ was identified in anionic fraction. Abollino et al. specified no other fractions. Out of a total amount of $\mathrm{Mn}$ in milk, $84.3 \%$ is in a soluble form.

The concentration of selenium in milk is lower compared to Se concentration in whole blood. In our group, milk Se concentration was $28.59 \pm 7.12 \mu \mathrm{g} / 1$ and a total volume of Se discharged through milk was $1007.15 \pm 280.45 \mu \mathrm{g}$. Michalke (2006) used speciation analysis to study individual fractions of Se in human milk. The selenium concentrations per species were determined in the low molecular weight (LMW) range as $2.5 \pm 0.2 \mu \mathrm{g} / \mathrm{l}$ (Se-carrying glutathione), $3.1 \pm 0.3 \mu \mathrm{g} / \mathrm{l}$ (Se-cystamine), $5.2 \pm 0.4 \mu \mathrm{g} / \mathrm{l}$ (Se-cystine) and $1.1 \pm 0.1 \mu \mathrm{g} / \mathrm{l}$ (Se-methionine). It is known that milk Se concentration varies depending on the geographic location and natural Se content in soil. Selenium is introduced into the food chain by plants that absorb inorganic selenium salts from the soil and convert them into organic forms of the element (mainly as selenomethionine); these are then incorporated into proteins. The concentration of selenium in plants varies widely and depends on the selenium content and characteristics of the soil. It has been found that supplementation of cattle's feed with organic forms of Se (as selenomethionine) increases Se concentration in milk (Knowles et al. 2006; Muniz-Naveiro et al. 2006; Givens et al. 2004; Heard et al. 2004; Juniper et al. 2006). We studied supplementation of different forms of Se in dairy goats, comparing sodium selenite, selenium proteinate, selenium yeast and lactateprotein complex. Pechová et al. (2008ab) found higher Se concentration in milk only after supplementation of selenium yeast, containing $63 \%$ Se as selenomethionine. Another possibility of increasing milk Se concentration is to apply inorganic selenium forms parenterally (Grace et al. 1997).

Correlations between concentrations of individual microelements in milk and other factors were evaluated using correlation analysis of the acquired data (Table 3). We did not find any significant correlations between milk and blood concentrations of the microelements. These results could be to some extent influenced by the fact that supplementation of dairy 
Table 3. Correlation coefficients between the concentration of individual microelements in serum/blood, daily milk yield, day of lactation and concentration of microelements in milk

\begin{tabular}{|l|c|c|c|c|}
\hline \multirow{2}{*}{ Correlation coefficients } & \multicolumn{3}{|c|}{ Concentration in milk } \\
\cline { 2 - 5 } & $\mathrm{Zn}$ & $\mathrm{Cu}$ & $\mathrm{Mn}$ & $\mathrm{Se}$ \\
\hline Daily milk yield & -0.221 & $-0.302^{*}$ & 0.097 & -0.205 \\
\hline Day of lactation & 0.153 & $-0.258^{*}$ & $0.419^{* *}$ & $-0.277^{*}$ \\
\hline Concentration of microelements in serum/blood & -0.145 & -0.185 & -0.096 & 0.181 \\
\hline
\end{tabular}

* $p<0.05$

$* * p<0.01$

cows with $\mathrm{Zn}, \mathrm{Cu}, \mathrm{Mn}$ and $\mathrm{Se}$ was good. Final verification of these correlations would require more extensive monitoring that would involve dairy cows from different herds, including herds showing signs of the deficiency disease. Wasowicz et al. (2001) found a significant linear correlation between concentrations of $\mathrm{Zn}$ in blood plasma and milk in the first stage of lactation and weak, but also significant linear correlations between $\mathrm{Se}$ concentration in the plasma and milk of women.

Similarly, we did not find a correlation between actual milk production and concentration of individual microelements in milk. Only the correlation between milk $\mathrm{Cu}$ concentration and daily milk production was significant $(\mathrm{r}=-0.302, p \leq 0.05)$. Negative correlation coefficients for $\mathrm{Cu}, \mathrm{Zn}$ and $\mathrm{Se}$ indicate a possible effect of the supplementation level on milk concentration of these microelements: high milk production means that a total intake of microelements recalculated per 1 litre of milk is lower. Although all dairy cows were fed a feed ration with the same concentration of nutrients, there could be individual differences in the total intake of dry matter and thus also in the total intake of microelements. From this perspective, the results indicate a link to the intake of microelements through the feed ration. It is likely that more significant correlations concerning supplementation would be found during marginal or insufficient supplementation of dairy cows with microelements.

Assessment of the effect of the lactation stage on the concentration of microelements was limited to days of lactation 7 to 188 , i.e. mature milk, as cows were not fed the same feed ration during the first week after parturition. Also, colostrum concentration of microelements was not the subject of this study. Some studies proved that concentrations of microelements are generally higher in colostrum than mature milk (Pavlata et al. 2004; Vaillancourt and Allen 1991). A significant correlation was found in milk Mn concentration that was increasing with days of lactation $(\mathrm{r}=0.419, p \leq 0.01)$. On the contrary, negative correlations were found in selenium and copper $(\mathrm{Cu}: \mathrm{r}=-0.258, p \leq 0.05$; Se: $\mathrm{r}=-0.277, p \leq 0.05)$. These correlations could be caused by depletion of $\mathrm{Se}$ and $\mathrm{Cu}$ body reserves with days of lactation (they are gradually lost through milk). There was no significant correlation between milk Zn concentration and days of lactation. As for the level of supplementation evaluated according to blood $\mathrm{Zn}$ concentration, the highest concentration of $\mathrm{Zn}$ in the feed ration was $105 \mathrm{mg} /$ $\mathrm{kg}$ of dry matter, which is almost twice as much as the recommended concentration. The unexpected tendency could be therefore caused by this high concentration of $\mathrm{Zn}$ in the feed ration. The concentration of microelements in milk during lactation was studied by Bedo et al. (1995). Their results show that the concentrations of $\mathrm{Zn}$ and $\mathrm{Cu}$ tended to decrease, while Mn showed non-significant variation during lactation.

Rodriguez et al. (2001) studied the effect of seasons on the concentration of microelements in pool milk samples. Their results show that Se concentration decreased from March to September, thus Se concentrations in cow's milk during winter and spring were significantly higher than those during summer and autumn. The content of $\mathrm{Cu}$ remained approximately constant during the year and the $\mathrm{Zn}$ concentration varied significantly, being lower in autumn than during winter and spring. On the other hand, O'Brien et al. (1999) found that the $\mathrm{Cu}$ content in milk was higher during the indoor period $(81.5 \mu \mathrm{g} / \mathrm{l})$ than 
during the outdoor grazing period $(55.1 \mu \mathrm{g} / \mathrm{l})$ and that $\mathrm{Zn}$ and $\mathrm{Mn}$ concentration in milk showed little variation over the year. In fact, these seasonal differences were probably caused by different contents of microelements in the feed ration.

In the herd showing sufficient supplementation with individual microelements, no significant correlations between concentrations of the microelements in milk and blood were found. The daily milk production influenced negatively only $\mathrm{Cu}$ concentration in milk, but Se, Zn and Mn was not influenced by its. During lactation after colostrum period the concentration of $\mathrm{Mn}$ in milk raised, the concentration of $\mathrm{Cu}$ and $\mathrm{Se}$ declined and the concentration of $\mathrm{Zn}$ was unchanged.

\section{Sledování obsahu Zn, Cu, Mn a Se v mléce ve vztahu k jejich koncentraci v krvi, nádoji a fázi laktace u dojnic}

Cílem této práce bylo zhodnocení vlivu aktuálního nádoje a fáze laktace na koncentrace Zn, Mn, Cu a Se v mléce a sledování vztahů mezi koncentrací stopových prvků v mléce a v krvi.

Sledování bylo realizováno v chovu holštýnského skotu s průměrnou dojivostí $8562 \mathrm{~kg}$ mléka za normovanou laktaci. Do sledování bylo zařazeno 35 dojnic ustájených v jedné skupině, u kterých byl proveden odběr krve a mléka při dvou po sobě jdoucích kontrolách užitkovosti s odstupem 4 týdny. Aktuální denní dojivost se u dojnic zařazených do sledování pohybovala od 19,6 až do 62,61. Z hlediska fáze laktace byly do hodnocení zařazeny výsledky vyšetření od 7 do 188 dní po porodu. Koncentrace jednotlivých prvků v krvi svědčila o dostatečném zásobení dojnic jednotlivými stopovými prvky. V krevním séru

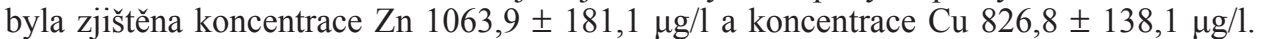
V plné krvi byla stanovena koncentrace Mn 14,0 $\pm 3,2 \mu \mathrm{g} / \mathrm{l}$ a Se 183,8 $\pm 29,6 \mu \mathrm{g} / \mathrm{l}$. Koncentrace jednotlivých stopových prvků v mléce byla následující: Zn 3855,2 \pm 814,7 $\mu \mathrm{g} / \mathrm{l}$; $\mathrm{Cu} 36,3 \pm 14,4 \mu \mathrm{g} / \mathrm{l} ; \mathrm{Mn} 20,1 \pm 8,3 \mu \mathrm{g} / \mathrm{l} ;$ Se 28,6 \pm 7,1 $\mu \mathrm{g} / \mathrm{l}$.

$\mathrm{V}$ chovu s dostatečnou supplementací jednotlivých stopových prvků jsme nenalezli signifikantní korelační vztahy mezi koncentrací stopových prvků v mléce a v krvi. Korelační vztahy mezi aktuálním nádojem a koncentrací sledovaných mikroprvků v mléce nebyly jednoznačně potvrzeny. Pouze mezi koncentrací mědi v mléce a denní dojivostí byl významný korelační vztah Cu: $\mathrm{r}=-0,302, p \leq 0,05)$. Mezi dnem laktace a koncentrací stopových prvků v mléce byl zjišsěn pozitivní korelační vztah $\mathrm{u} \mathrm{Mn}(\mathrm{r}=0,419, p \leq 0,01)$ a naopak negativní korelační vztahy byly zjištěny u $\mathrm{Cu}(\mathrm{r}=-0,258, p \leq 0,05$; Se: $\mathrm{r}=-0,277, p \leq 0,05)$. Výše denního nádoje ovlivnila negativně pouze koncentraci $\mathrm{Cu}$ v mléce, koncentrace $\mathrm{Se}, \mathrm{Zn}$ a Mn nebyla výší nádoje ovlivněna. S postupující laktací se koncentrace Mn v mléce zvyšovala, koncentrace $\mathrm{Cu}$ a Se naopak mírně klesala a koncentrace $\mathrm{Zn}$ v mléce se neměnila.

\section{Acknowledgement}

The study was carried out with the support of MSMT Projects No. MSM6215712402 and No. MSM6215712403.

\section{References}

ABOLLINO O, ACETO M, BRUZZONITI MC, MENTASTI E, SARZANINI C 1998: Speciation of copper and manganese in milk by solid-phase extraction/inductively coupled plasma-atomic emission spectrometry. Anal Chim Acta 375: 299-306

ANDERSON RR 1992: Comparison of trace elements in milk of four species. J Dairy Sci 75: 3050-3055

BEDO S, NIKODEMUSZ E, PERCSICH K, BARDOS L 1995: Variations in the milk yield and milk composition of dairy cows during lactation. Acta Vet Hung 43: 163-171

BENEMARIYA H, ROBBERECHT H, DEELSTRA H 1993: Zinc, copper, and selenium in milk and organs of cow and goat from Burundi, Africa. Sci Total Environ 128: 83-98

GEHRKE M, LACHOWSKI A 1997: Determination of manganese in cow blood using the flameless atomic absorption spectrophotometry. II. Population investigations into the variability of manganese concentrations in the serum and blood of cows in various production stages. Bull Vet Inst Puławy 41: 115-119 
GELFERT CC, STAUFENBIEL R 2000: Problems in diagnostic of manganese status in dairy cows by herd supervision. Tierarztl Prax Ausg Grob Nutz 28: 69-73

GIVENS DI, ALLISON A, COTTRILL B, BLAKE JS 2004: Enhancing the selenium content of bovine milk through alteration of the form and concentration of selenium in the diet of the dairy cow. J Sci Food Agric 84: 811-817

GRACE ND, LEE J, MILLS RA, DEATH AF 1997: Influence of Se status on milk Se concentrations in dairy cows. N Z J Agric Res 40: 75-78

HANSEN SL, SPEARS JW, LLOYD KE, WHISNANT CS 2006: Growth, reproductive performance, and manganese status of heifers fed varying concentrations of manganese. J Anim Sci 84: 3375-3380

HEARD JW, WALKER GP, ROYLE PJ, MCINTOSH GH, DOYLE PT 2004: Effects of short-term supplementation with selenium yeast on milk production and composition of lactating cows. Aust J Dairy Technol 59: 199-203

HERMANSEN JE, BADSBERG JH, KRISTENSEN T, GUNDERSEN V 2005: Major and trace elements in organically or conventionally produced milk. J Dairy Res 72: 362-368

JUNIPER DT, PHIPPS RH, JONES AK, BERTIN G 2006: Selenium supplementation of lactating dairy cows: Effect on selenium concentration in blood, milk, urine, and feces. J Dairy Sci 89: 3544-3551

KELLEHER SL, LONNERDAL B 2003: Zn transporter levels and localization change throughout lactation in rat mammary gland and are regulated by $\mathrm{Zn}$ in mammary cells. J Nutr 133: 3378-3385

KINCAID RL, CRONRATH JD 1992: Zinc concentration and distribution in mammary secretions of prepartum cows. J Dairy Sci 75: 481-848

KING JC 2002: Enhanced zinc utilization during lactation may reduce maternal and infant zinc depletion. Am J Clin Nutr 75: 2-3

KNOWLES SO, GRACE ND, KNIGHT TW, MCNABB WC, LEE J 2006: Reasons and means for manipulating the micronutrient composition of milk from grazing dairy cattle. Anim Feed Sci Technol 131: 154-167

LEGLEITER LR, SPEARS JW, LLOYD KE 2005: Influence of dietary manganese on performance, lipid metabolism, and carcass composition of growing and finishing steers. J Anim Sci 83: 2434-2439

LICATA P, TROMBETTA D, CRISTANI M, GIOFRE F, MARTINO D, CALO M, NACCARI F 2004: Levels of toxic and essential metals in samples of bovine milk from various dairy farms in Calabria, Italy. Environ Int 30: 1-6

MARTIN-HERNANDEZ C, AMIGO L, MARTIN-ALVAREZ PJ, JUAREZ M 1992: Differentiation of milks and cheeses according to species based on the mineral content. Z Lebensm Unters Forsch 194: 541-544

MICHALKE B 2006: Trace element speciation in human milk. Pure Appl Chem 78: 79-90

MILNER JA 1990: Trace minerals in the nutrition of children. J Pediatr 117: S147-S155

MORENO-ROJAS R, AMARO-LOPEZ M, ZURERA-COSANO G 1993: Micronutrients in natural cow, ewe and goat milk. Int J Food Sci Nutr 44: 37-46

MORENO-ROJAS R, AMARO-LOPEZ M, CANAL-RUIZ C, GARCIA-GIMENO R, ZURERA-COSANO G 1994: Mineral-content in Spanish sterilized milk. Rev Esp Cien Tecnol Alim 34: 323-332

MUNIZ-NAVEIRO O, DOMINGUEZ-GONZALEZ R, BERMEJO-BARRERA A, BERMEJO-BARRERA P, COCH JA, FRAGA JM 2006: Study of the bioavailability of selenium in cows' milk after a supplementation of cow feed with different forms of selenium. Anal Bioanal Chem 385: 189-196

O'BRIEN B, MEHRA R, CONNOLLY JF, HARRINGTON D 1999: Seasonal variation in the composition of Irish manufacturing and retail milk. Minerales and trace elements. Irish J Agr Food Res 38: 87-99

PAVLATA L, PECHOVÁ A, DVOŘÁK R 2004: Microelements in colostrum and blood of cows and their calves during colostral nutrition. Acta Vet Brno 73: 421-429

PAVLATA L, PECHOVÁ A, ILLEK J 2000: Direct and indirect assessment of selenium status in cattle - a comparison. Acta Vet Brno 69: 281-287

PECHOVÁ A, PAVLATA L, ILLEK J 2005: Blood and tissue selenium determination by hydride generation atomic absorption spectrophotometry. Acta Vet Brno 74: 483-490

PECHOVÁ A, PAVLATA L, LOKAJOVÁ E 2006: Zinc supplementation and somatic cell count in milk of dairy cows. Acta Vet Brno 75: 355-361

PECHOVÁ A, MIŠUROVÁ L, PAVLATA L, DVOŘ́́K R 2008a: Monitoring of changes in selenium concentration in goat milk during short-term supplementation of various forms of selenium, Biol Trace Elem Res 121: 180-191

PECHOVÁ A, JANŠTOVÁ B, MIŠUROVÁ L, DRAČKOVÁ M, VORLOVÁ L, PAVLATA L 2008b: Impact of supplementation of various selenium forms in goats on quality and composition of milk, cheese and yoghurt. Acta Vet Brno 77: 407-414

RINCON F, MORENO R, ZURERA G, AMARO M 1994: Mineral composition as a characteristic for the identification of animal origin of milk. J Dairy Res 61: 151-154

RODRIGUEZ EMR, ALAEJOS MS, ROMERO CD 2001: Mineral concentrations in cow's milk from the Canary Island. J Food Comp Anal 14: 419-430

SILVA FV, LOPES GS, NOBREGA JA, SOUZA GB, NOGUEIRAARA 2001: Study of the protein-bound fraction of calcium, iron, magnesium and zinc in bovine milk. Spectroc Acta Pt B-Atom Spectr 56: 1909-1916

UNDERWOOD EJ, SUTTLE NF 1999: The Mineral Nutrition of Livestock, $3^{\text {rd }}$ ed. CABI Publishing, Oxon.

VAILLANCOURT SJ, ALLEN JC 1991: Glucocorticoid effects on zinc transport into colostrum and milk of lactating cows. Biol Trace Elem Res 60: 185-196 
WASOWICZ W, GROMADZINSKA J, SZRAM K, RYDZYNSKI K, CIESLAK J, PIETRZAK Z 2001: Selenium, zinc and copper concentrations in the blood and milk of lactating women. Biol Trace Elem Res 79: 221-233

WINDISCH W 2002: Interaction of chemical species with biological regulation of the metabolism of essential trace elements. Anal Bioanal Chem 372: 421-425

ZADÁK Z 2002: Zinek. In: ZADÁK Z: Výživa v intenzivní péči. (Nutrition in intensive care). Grada Publishing, Praha, pp. 165-167

ZURERA-COSANO G, MORENO-ROJAS R, AMARO-LOPEZ M 1994: Effect of processing on contents and relationships of mineral elements of milk. Food Chem 51: 75-78 
